\title{
Dekapitasjon i allmennpraksis
}

Mutilering av fosteret ved f.eks. dekapitasjon lyder skrekkelig. Ved Rikshospitalets kvinneklinikk ble dette gjort 5-10 ganger årlig de første tiårene av det 20. århundre, men uhyre sjelden etter 1948 (1). Slike inngrep kunne også være aktuelle i allmennpraksis, slik distriktslege Knut Moe (1892-1972) på Stord beskrev i en kortfattet meddelelse i Tidsskriftet i 1939 (Tidsskr Nor Lægeforen 1939; 59: 1089-90).

Litteratur

1. Børdahl PE, Hem E. Endringer i norsk fødselshjelp i årene 1915-61. Tidsskr Nor Lægeforen 2004; 124: 3231 -4.

\section{Føtal tumor som fødselshindring}

For nogen år siden blev jeg kalt til en 31 år gammel 5 para. Hennes tidligere fødsler hadde hatt normalt forløp. Denne gang melder jordmor at der tross gode rier ikke var nevneverdig fremgang 12 timer efter utslettet mormunn. Undersøkelsen viste god fosterlyd, bakhodeleie, pilsømm i skråvidde og der blev lagt tang. Herved lyktes det såvidt å få hodet frem, men forsøk på videre forløsning på vanlig vis lyktes ikke; hodet satt som presset fast mot fødselsåpningen. Der blev gjort dekapitasjon, vending og uttrekning.

Efter dette inngrep var det en ikke ubehagelig overraskelse å se fosteret: Vekt med løst hode $6050 \mathrm{~g}$., lengde ca. $56 \mathrm{~cm}$., samtlige fullbårenhetstegn til stede. Der sees en svær, temmelig bløt, næsten slasket tumor som inntar venstre side av toraks og venstre arm til like ovenfor håndleddet. Tar man hensyn til fosterets dimensjoner for øvrig, kan man sikkert sette tumormassens vekt til godt og vel $2000 \mathrm{~g}$. Med lokalisasjon til venstre side av toraks og særlig venstre skulder- og overarmparti gir tumor tilstrekkelig forklaring på de mislykkede forløsningsforsøk.

Da jeg hadde interesse av å få nærmere oplysning om tumors art, blev liket sendt til Gades institutt, hvor tumor velvilligst blev undersøkt. Diagnose: Lymphangioma cavernosum. 